\title{
Kompetencje w późnym życiu. Głos w sprawie edukacji pozaformalnej
}

\begin{abstract}
This article aims to note the importance of non-formal education in the context of lifelong learning, especially in last phase. A secondary analysis of empirical research, conducted in Germany as part of a unique project "Competencies in Later Life" (CiLL), is the starting point for a reflection on the necessity of support of educational processes, enabling the development of qualifications after leaving formal education system. This study allowed to determine the level of competence of literacy, numeracy and problem solving in technology-rich environments of the population aged 66-80 years. The conclusions of the study are clear: in connection with a deficit of the core competencies of older people is needed educational offer. Participation in education can prevent exclusion from social life.
\end{abstract}

\section{Keywords:}

old age, ageing, research, adult education, non-formal education, Lifelong Learning

${ }^{1}$ Ewa Przybylska, Katedra Edukacji Dorosłych, Wydział Nauk Pedagogicznych, Uniwersytet Mikołaja Kopernika w Toruniu, Polska, evaprzyb@umk.pl. 


\section{EWOLUUJĄCE SPOJRZENIE NA STAROŚĆ W PERSPEKTYWIE PEDAGOGICZNEJ}

Pół wieku temu, gdy The Beatles zaśpiewali piosenkę „Will you still need me, will you still feed me, when I'm sixty-four?”2 panowało powszechne przekonanie o tym, że wraz z postępującym procesem starzenia się zanika zdolność człowieka do uczenia się. Nie było wówczas ani uniwersytetów trzeciego wieku, ani postulatów politycznych o konieczności uczenia się przez całe życie, ani wiedzy neurobiologicznej o plastyczności ludzkiego mózgu, zapewniającej zdolność uczenia się w każdym wieku.

Od tamtej pory zmienił się społeczny wizerunek człowieka starego. Zwłaszcza w krajach skandynawskich, zarówno w mediach, jak i świadomości społecznej, człowiek na emeryturze jest w coraz większym stopniu postrzegany jako aktywny członek społeczeństwa, posiadający potencjał, sprzyjający dalszemu rozwojowi osobistemu i dobru ogółu (Kruse, 2006, s. 13). Również w nauce nastąpiła zmiana paradygmatu; koncepcje akcentujące słabości i ryzyka związane z ostatnią fazą życia ustąpiły miejsca orientacji na silne strony ludzi starszych. Przypisuje się im dziś liczne przymioty, przesądzające o ich społecznej atrakcyjności: posiadają wiedzę specjalistyczną, ekspercką, zdobytą podczas pracy zawodowej, oraz wiedzę na temat innych dziedzin życia; potrafią zrobić z niej użytek dzięki różnym sprawdzonym strategiom działania; mają doświadczenie w komunikacji międzyludzkiej oraz czas i chęci, by służyć społeczeństwu (Kruse, 2006, s. 12-13).

Powszechne jest również przeświadczenie o tym, że efektywne wykorzystanie potencjału ludzi starszych, zarówno w okresie ich pracy zawodowej, jak i na emeryturze jest bez skutecznego systemu edukacji niemożliwe. Dostępne wyniki badań korzystania z ofert edukacyjnych pokazują wyraźnie, że uczestnictwo osób z wyższym wykształceniem ogólnym i zawodowym kształtuje się na poziomie znacznie przewyższającym poziom aktywności edukacyjnej osób o niższym wykształceniu, co - wraz ze starzeniem się - powoduje narastanie nierówności i poszkodowania społecznego osób, które w swoich biografiach nie mogą poszczycić się osiągnięciami edukacyjnymi (por. PISA, 2014).

Przez stulecia wiedza na temat potencjału ludzi starszych miała w dużej mierze charakter wrażeniowy i emocjonalny; wynikała z obserwacji środowiska społecznego lub subiektywnych odczuć osób o niej piszących. Tradycyjnie, począwszy od czasów starożytnych myśliciele doszukiwali się zalet starości i nie szczędzili

2 Tłum.: „Czy będziesz mnie jeszcze potrzebować, czy będziesz mnie jeszcze utrzymywać, gdy będę miał 64 lata?”. 
jej pochwał, akcentując przede wszystkim mądrość i doświadczenie życiowe ludzi w starszym wieku (por. Szarota, 2004, s. 12 i in.). Rosnące aktualnie zainteresowanie starością i uczeniem się w starości wiąże się ze zmianami demograficznymi i rozwojem społeczeństw wiedzy. Uczenie się ludzi starszych ma służyć nie tylko podniesieniu jakości ich życia, aktywności fizycznej i społecznej oraz poczuciu satysfakcji, ale także zwiększeniu konkurencyjności gospodarki i ogólnego dobrobytu. Wcale nie poza głównym nurtem dyskursu o starości, ukazują się dowody na rentowność inwestycji w edukację seniorów oraz oferty edukacyjne wspierające proces adaptacji do życia na emeryturze. Aktywna starość ogranicza wydatki społecznych systemów opieki i zdrowia (Tippelt, Schmidt, 2009, s. 13).

Współczesna nauka dysponuje dorobkiem teoretyczno-empirycznym potwierdzającym szereg atutów, które rozwijane i scalone w ludzkich biografiach rodzinnych, edukacyjnych, zawodowych i społecznych tworzą kapitał własny jednostki. Pedagogika spogląda na starość z trzech perspektyw: indywidualnych poznawczo-intelektualnych właściwości jednostki, kontynuacji biograficznych procesów uczestnictwa w edukacji i doświadczeń w sferze uczenia się oraz, po trzecie, interakcji społecznych, które buduje człowiek starszy (Schmidt-Hertha, 2014, s. 37). Interesuje ją przede wszystkim umiejętność uczenia się w starości, która w świetle współczesnych badań jest w większym stopniu wynikiem biograficznych doświadczeń w dziedzinie uczenia się niż zdolności kognitywnych (Schmidt-Hertha, 2014, s. 37).

\section{ZAŁOŻENIA PROJEKTU BADAWCZEGO „COMPETENCIES IN LATER LIFE” (CILL)}

O ile biografie ludzi starszych budzą od kilku dziesięcioleci żywe zainteresowanie badaczy, o tyle pomiarowi poziomu kompetencji ludzi starszych nie poświęcono dotychczas szczególnej uwagi. Obszerne międzynarodowe studia porównawcze (IALS, PISA, PIAAC ${ }^{3}$ ), zainicjonowane w latach 90. ubiegłego wieku przez OECD, koncentrowały się na kompetencjach ludzi nie przekraczających 65. roku życia, uczestniczących w edukacji formalnej lub będących w wieku produkcyjnym. Wszak w badaniach chodzi na ogół o relacje pomiędzy kompetencjami a rynkiem pracy i rozwojem gospodarczym. Raz tylko, w ramach International Adult Lite-

${ }^{3}$ IALS - International Adult Literacy Survey (Międzynarodowe badanie umiejętności dorosłych w zakresie czytania i pisania); PISA - Programme for International Student Assessment (Program Międzynarodowej Oceny Umiejętności Uczniów); PIAAC - Programme for the International Assessment of Adult Competencies (Międzynarodowe Badanie Kompetencji Osób Dorosłych). 
racy Survery (IALS) przebadano dodatkowo, w Kanadzie, populację osób, które przekroczyły 65. rok życia. Wynik pokazał, że kompetencje w dziedzinie czytania i pisania 80\% respondentów kształtują się na najniższym poziomie zastosowanej skali (por. Przybylska, 2014, s. 428).

Unikatowe na skalę europejską badania kompetencji ludzi starszych przeprowadzono w Niemczech w ramach projektu „Competencies in Later Life” (CiLL), który skoncentrował się na pominiętej przez OECD grupie wiekowej 66-80 lat, czyli osobach urodzonych w latach 1931-1946, w których biografiach zaznaczył się okres II wojny światowej lub pierwsze lata powojenne (Friebe i in., 2014). Bezpośredniemu pomiarowi poddano trzy rodzaje kompetencji: kompetencje rozumienia tekstu, rozumowania matematycznego oraz wykorzystywania technologii informacyjno-komunikacyjnych. Definicje kompetencji przyjęto za PIAAC ${ }^{4}$. Zastosowano również tę samą skalę pomiaru kompetencji o zakresie od 0 do 500 punktów, którą podzielono na sześć poziomów kompetencji dla rozumienia tekstu i kompetencji matematycznych oraz na cztery poziomy w przypadku kompetencji wykorzystywania technologii informacyjno-komunikacyjnych. Badaniami objęto 1392 osoby, z tego 54\% stanowiły kobiety, 46\% mężczyźni. Średnia wieku badanych wynosiła 72 lata. W ramach edukacji szkolnej ponad połowa badanych (59\%) zdobyła wykształcenie podstawowe; 16\% osób ukończyło szkoły średnie; 14\% uzyskało świadectwo maturalne, 11\% nie ukończyło żadnej szkoły. Spośród badanych 18\% nie posiadało żadnego wykształcenia zawodowego; 14\% - wykształcenie wyższe; pozostali zdobywali kwalifikacje zawodowe w różnych formach kształcenia ustawicznego.

Testy kompetencji uzupełniono o wyniki badań jakościowych, obejmujących studia przypadków, badania fokusowe oraz pogłębione wywiady eksperckie. Chodziło o rozpoznanie relacji pomiędzy kompetencjami a intensywnością ich wykorzystywania w życiu codziennym, aktywnościami społecznymi i uczestnictwem w edukacji dorosłych.

${ }^{4}$ Kompetencje rozumienia tekstu definiowane są jako umiejętność rozumienia i oceny informacji zawartych w tekstach pisanych oraz wykorzystanie tych informacji do udziału w życiu społecznym, osiągania własnych celów oraz rozwoju własnej wiedzy i potencjału. Rozumowanie matematyczne zdefiniowano jako zdolność wykorzystania, interpretacji i komunikowania informacji oraz pojęć matematycznych w różnych sytuacjach życia prywatnego i zawodowego wymagających wiedzy i umiejętności matematycznych. Kompetencje związane z wykorzystywaniem technologii informacyjno-komunikacyjnych w PIAAC to umiejętności wykorzystania komputera oraz Internetu do pozyskiwania i analizy informacji, porozumiewania się z innymi oraz wykonywania praktycznych zadań w kontekstach prywatnym, zawodowym i społecznym (por. IBE, 2014, s. 2). 


\section{KOMPETENCJE W PÓŹNEJ FAZIE ŻYCIA W ŚWIETLE BADANIA "COMPETENCIES IN LATER LIFE" (CILL)}

W odniesieniu do „rozumienia tekstu” badanie wykazało, że bardzo niskie kompetencje rozumienia tekstu (poniżej poziomu pierwszego) posiada $8,5 \%$ badanych (co odpowiada 1062976 osób z populacji liczącej 12505600 osób urodzonych w latach 1931-19465); umiejętności na pierwszym poziomie skali posiada 29\% badanych (3 644 141); największa grupa badanych (46\% = 5715059 osób) plasuje się na poziomie drugim skali; 16\% (1 963379 osób) - na poziomie trzecim; na poziomie czwartym - 0,9\% kohorty (112 550 osób); piątego poziomu skali nie osiągnęła żadna z badanych osób.

W obszarze „kompetencje w dziedzinie rozumowania matematycznego” większość populacji klasyfikuje się na poziomie drugim (42\%) oraz poziomie trzecim (21\%). Kompetencje poniżej poziomu pierwszego posiada 9,8\% badanych, niemal co czwarty badany $(24,8)$ posiada kompetencje na poziomie pierwszym. $\mathrm{Na}$ drugim biegunie skali uplasowało się odpowiednio: na poziomie czwartym - 2,8\% respondentów i na poziomie piątym - 0,1\%.

Spośród 1392 osób w wieku 66-80 lat uczestniczących w badaniu tylko 395 osób wyraziło gotowość poddania się testom kompetencji związanych z wykorzystywaniem technologii informacyjno-komunikacyjnych. Ostatecznie, po wyłączeniu respondentów nieradzących sobie z obsługą klawiatury, zakwalifikowano do nich 364 osoby (25\% próby badawczej). Żadna z nich nie osiągnęła najwyższego, trzeciego poziomu skali; na poziomie drugim uplasowało się 2,6\% badanych, na poziomie pierwszym - około 11\%, a poniżej poziomu pierwszego - niemal 13\%.

Tab. 1. Procentowy rozkład kompetencji rozumienia tekstu i rozumowania matematycznego

\begin{tabular}{lllllll}
\hline Kompetencja & $\begin{array}{l}\text { Poniżej } \\
\text { poziomu I }\end{array}$ & $\begin{array}{l}\text { Poziom } \\
\text { I }\end{array}$ & $\begin{array}{l}\text { Poziom } \\
\text { II }\end{array}$ & $\begin{array}{l}\text { Poziom } \\
\text { III }\end{array}$ & $\begin{array}{l}\text { Poziom } \\
\text { IV }\end{array}$ & $\begin{array}{l}\text { Poziom } \\
\text { V }\end{array}$ \\
\hline $\begin{array}{l}\text { Rozumienie } \\
\text { tekstu }\end{array}$ & 8,5 & 29,3 & 45,6 & 15,7 & 0,9 & 0,0 \\
\hline $\begin{array}{l}\text { Rozumowanie } \\
\text { matematyczne }\end{array}$ & 9,8 & 24,8 & 41,5 & 20,8 & 2,8 & $0,1^{*}$ \\
\hline
\end{tabular}

* Niewielki odsetek testów nie został uwzględniony przy ocenie wyników. Źródło: Opracowanie własne na podstawie: Friebe i in., 2009, s. 60-88.

5 Dane pochodzą z mikrospisu z 2011 roku. 
Kompetencje na poziomie pierwszym oznaczają bardzo niskie umiejętności w zakresie czytania, pisania lub liczenia. Osoby, których kompetencje plasują się na tym poziome z trudem znajdują w tekście potrzebną informację. Potrafią ją zrozumieć, o ile jest wyrażona w bezpośredni i najprostszy sposób. Kompetencje na poziomie poniżej pierwszego wykluczają z komunikacji pisemnej i wszelkich aktywności z zastosowaniem liczb. Do obu tych poziomów, utożsamianych z analfabetyzmem funkcjonalnym, zakwalifikowano zarówno w przypadku kompetencji rozumienie tekstu, jak i rozumowania matematycznego ponad jedną trzecią badanych. Poziom kompetencji związanych z wykorzystywaniem technologii informacyjno-komunikacyjnych świadczy o jeszcze większych deficytach badanej populacji.

Tab. 2 Procentowy rozkład kompetencji związanych z wykorzystywaniem technologii informacyjno-komunikacyjnych

\begin{tabular}{llll}
\hline Poniżej poziomu I & Poziom I & Poziom II & $\begin{array}{l}\text { Nieuczestniczący } \\
\text { w badaniu }\end{array}$ \\
\hline 12,7 & 10,8 & 2,6 & 73,9 \\
\hline
\end{tabular}

Źródło: Opracowanie własne na podstawie: Friebe i in. 2009, s. 106-108.

Wiedzę o tym, jakiego rodzaju kompetencje badani uważają za najbardziej istotne w swojej codzienności, uzyskano w wyniku badań jakościowych, w tym fokusowych, z czterema grupami: starszymi osobami pracującymi zawodowo, osobami zaangażowanymi w wolontariat, osobami pielęgnującymi członka rodziny i grupą migrantów i migrantek, wyselekcjonowanych spośród grupy badawczej poddanej testom pomiaru kompetencji.

Wśród przebadanej populacji osób starszych pracujących zawodowo znalazły się osoby w wieku 65-77 lat z różnym wykształceniem. Niemal połowa z nich (46,6\%) posiadała wykształcenie średnie, 22,3\% wyższe wykształcenie akademickie, 18,1\% wyższe wykształcenie zawodowe; jedynie 13\% legitymowało się niskimi kwalifikacjami. Kompetencje w dziedzinie czytania i pisania uznali za nieodzowne przy wykonywaniu czynności zawodowych. Kompetencje matematyczne ocenili jako bardziej istotne w życiu codziennym niż zawodowym. Kompetencje informacyjno-komunikacyjne wykorzystują jedynie do obsługi poczty elektronicznej i systemów nawigacyjnych. Poza kompetencjami stanowiącymi przedmiot badania w ramach CiLL, za kompetencje ważne w kontekście swojej działalności zawodowej uznali kompetencje w dziedzinie planowania przebiegu dnia i organizowania poszczególnych aktywności, radzenia sobie w sytuacjach konfliktowych 
w miejscu pracy oraz umiejętność prowadzenia dialogu z młodszymi generacjami. Część badanych przyznała się do uczestnictwa w kursach wspierających rozwój kompetencji społecznych.

Respondenci zaangażowani w pracę społeczną i wolontariat wskazali na kompetencję czytania jako najbardziej podstawową w ich działalności społecznej. Piszą wnioski do urzędów, petycje, czytają swoim podopiecznym książki. Mniejsze znaczenie przypisali kompetencji matematycznej. Kompetencje informatyczno-komunikacyjne uznali za warunek komunikowania się, uzgodnień terminów i innych kwestii oraz pozyskiwania wiedzy i informacji ze stron internetowych. Do kompetencji potrzebnych w wolontariacie zaliczyli ponadto kompetencje organizacyjne, komunikację interpersonalną, empatię oraz postawę otwartości na problemy innych ludzi.

Wywiady z osobami pielęgnującymi członka rodziny uwypukliły specyfikę ich sytuacji życiowej, wymagającej sprostaniu szeregowi zadań, jak choćby upewnienie się co do wysokości należnych świadczeń socjalnych, prowadzenie budżetu domowego z uwzględnieniem wydatków na osobą pielęgnowaną, adaptacja mieszkania do jej potrzeb czy zapewnienie odpowiedniego sprzętu do rehabilitacji. Badani uznali, że umiejętności czytania, liczenia i obsługi komputera są nieodzowne przy wywiązywaniu się z codziennych obowiązków. Kompetencja w dziedzinie czytania umożliwia m.in. aktualizację wiedzy na temat nowoczesnych metod pielęgnacji; kompetencja matematyczna jest potrzebna do odpowiedniego dawkowania leków czy kalkulacji kosztów zakupu środków pielęgnacyjnych; wykorzystanie komputera pozwala na zdobycie informacji i porad oraz uczestnictwo w forach grup wzajemnego wsparcia. Respondenci wyrazili przekonanie, że najtrudniejszym wyzwaniem w ich sytuacji życiowej jest pogodzenie się ze zbliżającym się odejściem bliskiej osoby.

Członkowie grupy migranckiej, władający językiem niemieckim w większym stopniu w mowie niż piśmie przyznali, że kompetencja czytania w ich sytuacji życiowej jest ważna, ponieważ umożliwia zapoznanie się z informacjami w gazetach i Internecie na temat ich kraju pochodzenia. Podobnie oceniają kompetencję informatyczno-komunikacyjną, umożliwiającą szybki i regularny kontakt z rodziną żyjącą zagranicą. Braku kompetencji w dziedzinie pisania i obsługi komputera nie odczuwają jednak jako bolesnego deficytu, gdyż mogą liczyć na pomoc dzieci, które radzą sobie z pisaniem i obsługą komputera. Kompetencje w dziedzinie liczenia (w pamięci) wykorzystują głównie przy dokonywaniu płatności w kasie. 


\section{WNIOSKI Z BADAŃ. O POTRZEBIE EDUKACJI PODSTAWOWEJ DOROSŁYCH}

Badanie CiLL wzbogaciło wiedzę na temat poziomu kompetencji pisania, liczenia i obsługi nowoczesnych technologii przez osoby po 65. roku życia. Porównanie osiąganych przez nie wyników w testach z wynikami uzyskanymi w młodszych grupach wiekowych (badanie PIACC) wskazuje na niższy poziom kompetencji osób starszych. W przypadku kompetencji rozumienia tekstu 37,8\% respondentów w przedziale wiekowym 65-80 lat zakwalifikowało się do poziomu pierwszego lub poniżej pierwszego, podczas gdy w badaniu PIACC obejmującym populację 16-65 lat było 17,5\% badanych, przy czym w najstarszej subgrupie 55-65 lat 24\%. Podobne tendencje zaobserwowano w przypadku kompetencji matematycznych. Drastyczne różnice pokoleniowe wystąpiły przede wszystkim w dziedzinie kompetencji informatyczno-komunikacyjnej.

Jakkolwiek by interpretować wyniki badania, wskazują one klarownie na potrzebę uczestnictwa osób starszych w edukacji dorosłych na poziomie podstawowym, wspierającej rozwój poszczególnych kompetencji, i jednoznacznie potwierdzają konieczność organizowania kursów czytania, liczenia i obsługi komputera dla seniorów. Wzmacniają tym samym przyjętą przez niemiecką politykę oświatową strategię rozwoju sektora „edukacji podstawowej dorosłych”. Pojęcie „edukacja podstawowa dorosłych” wypiera aktualnie tradycyjne pojęcie „alfabetyzacja”, nawiązujące bezpośrednio do nauki czytania, pisania i liczenia i ograniczające zakres kursów do rozwoju tych umiejętności (Boltzmann i in., 2015, s. 11). Za pojęciem „edukacja podstawowa” przemawia coraz bardziej powszechne przekonanie o nieodzowności posiadania, obok tych fundamentalnych, także szeregu innych umiejętności, warunkujących sprawne funkcjonowanie w rodzinie, pracy, partycypację w życiu kulturalnym, obywatelskim i innych obszarach społecznych. W pracy oświatowej brak kompetencji czytania i pisania lub liczenia stanowi pretekst do włączenia osób posiadających ten deficyt do procesów nauczania-uczenia się umożliwiających także rozwój kompetencji osobistych, społecznych, technologicznych czy kompetencji uczenia się. Tradycyjna alfabetyzacja jest współcześnie tylko jednym z wielu obszarów edukacji podstawowej dorosłych. Z perspektywy ludzi starszych niemałe znaczenie mogą odgrywać także podstawowa edukacja zdrowotna, żywieniowa, ekonomiczna czy polityczna, które - podobnie jak kompetencje w dziedzinie czytania, liczenia i obsługi komputera - nie pozostają bez wpływu na jakość życia w starości. Definicje współczesnej edukacji podstawowej dorosłych ujmują ją jako pojęcie znacznie przekraczające ramy tradycyjnej alfabetyzacji, akcentując, że jej treści 
są uwarunkowane minimalnymi wymogami społecznymi wynikającymi ze zmian kulturowych, gospodarczych i technologicznych oraz sytuacjami życiowymi i ambicjami jednostek i grup społecznych (Mania, Tröster, 2015, s. 10). Nie ulega wątpliwości, że wymogi kompetencyjne wobec ludzi starszych rosną. Przykładowo, choćby za edukacją ekonomiczną na poziome podstawowym przemawia zwyżkujące zadłużenie gospodarstw domowych, częste zmiany w systemach emerytalnych wiążące się z koniecznością podejmowania indywidualnych decyzji odnośnie do oszczędzania i inwestowania na przyszłość czy wymóg konstruowania budżetu domowego w sytuacji skromniejszych dochodów po przejściu na emeryturę i licznych alternatyw wyboru dotyczących konsumpcji.

Badaniie CiLL potwierdziło również, że mimo dobrze rozbudowanej i sprawnie funkcjonującej w Niemczech infrastruktury edukacji dorosłych, w tym edukacji seniorów, szereg barier niezmiennie ogranicza aktywność edukacyjną ludzi starszych. W kursach z zakresu czytania i pisania, mimo że ich liczba z roku na rok rośnie, uczestniczy tylko niewielki odsetek populacji osób niepiśmiennych (Huntemann, Reichart, 2015, s. 256). Przyczyny bierności edukacyjnej są zróżnicowane. Dla jednych barierą jest odległość dzieląca miejsce zamieszkania od instytucji edukacyjnej; inni nie widzą potrzeby uczenia się bądź rezygnują z uczestnictwa w kursie z powodów finansowych (Boltzmann i in., 2015, s. 25). W sytuacji deficytu kompetencji społecznie uznanych za podstawowe, jak np. czytanie i pisanie, dodatkową barierę tworzy niechęć do publicznego obnażenia się jako osoba niespełniająca powszechnie obowiązujących standardów oraz obawa przed poniesieniem, być może kolejnej już, porażki edukacyjnej.

Wyraźnie widać korelacje między wykształceniem i stylem życia a poziomem kompetencji. Badanie, umożliwiając poznanie intensywności, z jaką badani wykonywali określone czynności związane z mierzonymi kompetencjami, oraz zmian zachodzących w ich wykorzystaniu wraz z postępującym wiekiem i zmieniającym się charakterem aktywności społecznej, podkreśla zarówno rolę biografii edukacyjnych jednostek, jak i społecznych determinantów uczenia się w starości. Rozwojowi kompetencji sprzyja wszelkiego rodzaju aktywność społeczna, ale także najbliższe środowisko rodzinne, które może animować do uczenia się lub stać jemu na przeszkodzie. Dialog międzypokoleniowy w rodzinie, inspiracja seniorów do otwarcia się na nowe technologie czy czerpanie przez młodych z ich doświadczenia życiowego stanowią bodziec dla procesów uczenia się ludzi starszych.

${ }^{6}$ Autorka powołuje się na statystyki uniwersytetów powszechnych, największego w Niemczech oferenta edukacji ogólnej. 
Badanie potwierdziło ponadto, że mimo różnorodności biografii respondentów, ich losy wskazują na specyficzne dla pokolenia seniorów cechy wspólne: nieliczni mieli szansę na zdobycie wykształcenia wyższego; wyuczony zawód zapewniał dochody pozwalające na zaspokojenie podstawowych potrzeb; nie musieli ani obawiać się konkurencji na rynku pracy, ani zmagać się z presją wywieraną przez postulat uczenia się przez całe życie.

\section{EDUKACJA POZAFORMALNA: KILKA UWAG Z PERSPEKTYWY POLSKIEJ}

Edukacja dorosłych ma na celu pomóc ludziom w przezwyciężaniu wyzwań wyłaniających się na różnych etapach życia: ludziom starszym w dokonaniu bilansu życiowego, który stanowi jedno z zadań rozwojowych jednostki. Ma otworzyć przed ludźmi starszymi nowe pola aktywności kulturalnej i społecznej oraz wspierać ich adaptację do zmieniających się warunków życia. Liczne studia potwierdzają relację między poczuciem satysfakcji życiowej i zdrowiem a aktywnym trybem życia (por. McNair, 2010, s. 54-64). Polskie badania nad aktywnością społeczną i edukacyjną populacji 50+ pokazują, że na tle innych krajów europejskich kształtuje się ona na jednym z najniższych poziomów (IBE i in., 2014).

Obok funkcji kompensacyjnych, wyrównawczych, ogólnorozwojowych czy kulturotwórczych ma też edukacja dorosłych przeciwdziałać wykluczeniu społecznemu, na które narażona jest populacja ludzi starszych w dwojaki sposób. Po pierwsze, z wiekiem zwiększa się niepełnosprawność fizyczna, maleje mobilność, pogarsza się wzrok i słuch, nasilają się objawy chorób chronicznych (nadciśnienie, cukrzyca itp.), ograniczając możliwości pełnej partycypacji społecznej. Po drugie, warunkiem inkluzji jest posiadanie przez jednostki podstawowych kompetencji w zakresie rozumienie tekstu, matematyki, wykorzystywania technologii informacyjno-komunikacyjnych i wielu innych, istotnych w relacjach społecznych. W świetle międzynarodowych badań porównawczych kompetencji w Polsce osoby w przedziale wiekowym 55-65 lat wypadają gorzej niż młodsze kohorty, stanowiąc tzw. „grupę ryzyka” (por IBE i in., 2014, s. 62). Polski raport z badań PIACC stwierdza m.in: „Ogólne zróżnicowanie wyników jest w Polsce najmniejsze w najmłodszych grupach wieku, w których wiele osób nadal się kształci lub zakończyło edukację formalną stosunkowo niedawno. Zapewne różne doświadczenia na rynku pracy - posiadanie lub nieposiadanie pracy, praca w różnych sektorach i zawodach - sprawiają, że osoby powyżej 25. roku życia w różnym stopniu rozwijają, podtrzymują lub tracą swoje umiejętności” (IBE 
i in., 2014, s. 62). Hipoteza jest przekonująca, niemniej fenomen zaprzepaszczania kompetencji w biegu życia musi generować pytania o kondycję edukacji dorosłych, o zaangażowanie polityki w kształtowanie warunków do uczenia się przez całe życie, o bariery w dostępie do edukacji. Muszą istnieć, skoro dorośli zamiast rozwijać się przez całe życie doświadczają regresu. Dlatego, że nie nadążają za zmianami? Dlatego, że nie uczą się? Dlatego, że nie chcą się uczyć? Może dlatego, że nie widzą potrzeby, żeby się uczyć. Jakkolwiek by było, kuriozalnie brzmią polityczne wyjaśnienia odnośnie do niskiej aktywności edukacyjnej dorosłych Polaków: „Poziom uczestnictwa w kształceniu i szkoleniu osób od 25. do 64. roku życia pozostaje w kontraście do dynamicznego rozwoju edukacji osób do 24. roku życia. [...] europejski wskaźnik uczestnictwa dorosłych w LLL dotyczy osób od 25. roku życia, gdy tymczasem polską specyfiką w kształceniu i szkoleniu dorosłych są dobre wyniki w edukacji osób młodszych - do 24. roku życia” (Rada Ministrów, 2013, s. 17-18). Decydenci polityczni w cytowanym dokumencie, zwracają uwagę na „specyficzne podejście do kształcenia w Polsce, w którym kształcenie identyfikuje się głównie z edukacją formalną”. Zmiana elit rządzących w październiku 2015 roku nie przyniosła zmian w podejściu do systemu edukacji. Toczy się debata o sześciolatkach w szkole, reformie szkół powszechnych i potrzebie zmiany zawartości podręczników szkolnych. Edukacja dorosłych, edukacja pozaformalna pozostają tematem tabu, kwestią niezauważaną, niemal nieuchwytną w przestrzeni publicznej. W raportach, sporządzanych z obowiązku członkostwa w Unii Europejskiej zawsze można wskazać na rozkwit uniwersytetów trzeciego wieku, które, paradoksalnie, są inicjatywą całkowicie oddolną, korzystającą z minimalnego wsparcia budżetów publicznych. Utrzymują się głównie z czesnego, darowizn, dotacji organizacji pozarządowych czy grantów. Skromny budżet ogranicza liczbę słuchaczy oraz ofertę programową.

Neoliberalna polityka oświatowa przyzwala na komercjalizację pozaformalnej edukacji dorosłych, nie bacząc na rosnące ograniczenia w dostępie do niej i selektywny, bo zgodny z logiką rynku, dobór treści edukacyjnych. W takim modelu oświaty nie ma miejsca dla seniorów, których jedynym źródłem dochodów są świadczenia emerytalne lub inne świadczenia społeczne.

Problem można rozpatrywać przez pryzmat wielu aspektów. Jednym z nich jest kwestia inkluzji - ekskluzji społecznej, w której całożyciowej edukacji przypada zaszczytne miejsce. Warto zaakcentować przymiotnik „,całożyciowej”, bo jak widać, wysokie wskaźniki edukacji formalnej dzieci i młodzieży nie gwarantują rozwoju kompetencji w późniejszych fazach życia. Można by, powołując się na wyniki badania CiLL, rzec: za naszymi granicami jest nie inaczej. A jednak jest inaczej. Za naszą zachodnią granicą trwa od 2015 roku „dekada alfabetyzacji 
i edukacji podstawowej dorosłych” (BMBF, 2015), zainicjowana m.in. wynikami badań PIAAC i CiLL, dokumentującymi potrzebę przekazu podstawowych technik kulturowych i kompetencji osobom dorosłym, także w wieku senioralnym.

Pozostawienie sektora edukacji pozaformalnej dorosłych regułom wolnego rynku niesie negatywne skutki społeczne i pozbawia dorosłych w każdym wieku szans na szeroko rozumiany rozwój. Negatywne następstwa tego zaniedbania kumulują się zwłaszcza w ostatniej fazie życia człowieka. „Starość nie jest okresem oderwanym od reszty życia” (Steuden, 2012, s. 213). Jest czasem kontynuacji doświadczeń i zainteresowań edukacyjnych minionych lat, tyle że więcej w nim barier zdrowotnych, ekonomicznych i innych.

\section{Literatura:}

BMBF (2015). Nationale Strategie für Alphabetisierung und Grundbildung Erwachsener. Pobrane z www.bmbf.de/de/426.php.

Bolzmann, M., Aulbert-Siegelmeyer, A., Rüsseler, J., Warnke, R., Menkhaus, K., Overlander, O. (2015). AlphaPlus. Ein Alphabetisierungsprogramm zur Förderung der Schriftsprachkompetenz Erwachsener. Bielefeld: W. Bertelsmann Verlag.

Friebe, J., Schmidt-Herta, B., Tippelt, R. (red.), (2014). Kompetenzen im höheren Lebensalter. Ergebnisse der Studie „Competencies in Later Life” (CiLL). Bielefeld: W. Bertelsmann Verlag.

Huntemann, H., Reichart, E. (2015). Volkshochschul-Statistik: 53. Folge, Arbeitsjahr 2014. Bonn: DIE.

IBE (2014). Umiejętności Polaków - Wyniki Międzynarodowego Badania Kompetencji Osób Dorosłych (PIAAC). Warszawa: IBE.

IBE, Centrum Analiz Ekonomicznych, Szkoła Główna Handlowa w Warszawie, Uniwersytet Jagielloński - Collegium Medicum, UW - Wydział Nauk Ekonomicznych (2014). Portret generacji 50+ w Polsce i Europie. Wyniki badania zdrowia, starzenia się i przechodzenia na emeryturę w Europie (SHARE). Warszawa: IBE.

Kruse, A. (2006). Altern, Kultur und gesellschaftliche Entwicklung. Report Zeitschrift für wissenschaftliche Weiterbildungsforschung, 3, s. 9-18.

Mania, E., Tröster, M. (2015). Finanzielle Grundbildung. Programme und Angebote planen. Bielefeld: W. Bertelsmann Verlag.

Przybylska, E (2014). Analfabetyzm funkcjonalny dorosłych jako problem społeczny, egzystencjalny i pedagogiczny. Toruń: Wydawnictwo Naukowe Uniwersytetu Mikołaja Kopernika.

Rada Ministrów (2013). Załącznik do uchwały z dnia 10 września 2013 roku Nr 160/2013. Perspektywa uczenia się przez całe życie: Pobrane z: https://men.gov.pl/wp-content/ uploads/2014/01/plll_2013_09_10zal_do_uchwaly_rm.pdf.

Schmidt-Hertha, B. (2014). Kompetenzerwerb und Lernen im Alter. Bielefeld: W. Bertelsmann Verlag. 
Steuden S. (2012). Psychologia starzenia się i starości. Warszawa: Wydawnictwo Naukowe PWN.

Szarota, Z. (2004). Gerontologia społeczna i oświatowa. Zarys problematyki. Kraków: Wydawnictwo Naukowe Akademii Pedagogicznej.

Tippelt, R., Schmidt, B. (2009). Demografische Entwicklung und die Bildung Älterer. W: R. Tippelt, B. Schmidt, S. Schnurr, S. Sinner, C. Theisen (red.), Bildung Älterer. Chancen im demografischen Wandel (s. 12-19). Bielefeld: W. Bertelsmann Verlag. 